\title{
KINERJA GURU SERTIFIKASI PADA MADRASAH ALIYAH SWASTA (MAS) PLUS PADANG GANTING KABUPATEN TANAH DATAR
}

\author{
Syafriadi $M$ \\ Guru PAI MAS Plus Padang Ganting \\ Email: Syafaraha@gmail.com
}

\begin{abstract}
In this case study of qualitative approach the researcher analyzed the performance of civil servant and non civil servant teachers after certification. This research was conducted in Private Islamic High School (MAS) Plus Padang Ganting Tanah Datar. This research revealed that the civil servant teachers were better than non-civil servant teachers. Some of non civil servant teachers did not make lesson plan, did not make remedial program and an enriching program.
\end{abstract}

Keywords: Teachers' Performance, Private Islamic High School Plus Padang Ganting, Teachers' Certification

\section{PENDAHULUAN}

Sekolah merupakan institusi yang sangat berkaitan dengan upaya sadar pembentukan pribadi seseorang yang diharapkan selaras dengan tuntunan budaya manusia yang semakin tinggi. Peran sekolah sangat kompleks, bukan saja masukannya yang bervariasi, melainkan dari proses pembelajaran yang diselenggarakannya. Sekolah tidak akan menjadi baik dengan sendirinya, melainkan dengan proses peningkatan segala aspek yang ada di dalam sekolah. Untuk mencapai pendidikan dan pembelajaran yang berkualitas, suatu lembaga pendidikan sebagai suatu sistem, dipengaruhi oleh berbagai komponen seperti program kegiatan pembelajaran, peserta didik, sarana-prasarana pembelajaran, pembiayaan, lingkungan masyarakat, kepemimpinan kepala sekolah, guru dan faktor-faktor lainnya.

Proses peningkatan mutu pendidikan dan sumber daya manusia di sekolah memerlukan guru baik secara individu maupun kolaboratif untuk mengubah suatu kondisi agar pendidikan dan pembelajaran menjadi lebih bermutu dan berkualitas. Perubahan itu tidak mungkin terjadi begitu saja tanpa ada usaha dan motivasi kerja yang maksimal dari pengampuh pendidikan, sebagaimana firman Allah SWT. Dalam Al-Qur'an Surat Ar-Ra’du ayat 
11 "Sesungguhnya Allah tidak mengubah keadaan sesuatu kaum kecuali jika mereka mengubah keadaan diri mereka sendiri”.

Keterlibatan guru dalam aktivitas kerja penting untuk diperhatikan, sehingga mereka mau dan senang bekerjasama baik dengan pimpinan ataupun dengan sesama teman kerja. Salah satu cara yang dapat dipakai untuk mendorong keterlibatan guru adalah dengan mengajak partisipasi dan melakukan koordinasi dengan mereka dalam berbagai kesempatan pembuatan keputusan, yang dapat menumbuhkan keyakinan pada guru bahwa apa yang telah diputuskan merupakan keputusan bersama. Di samping itu, dengan melakukan hal tersebut, guru merasakan bahwa mereka diterima sebagai bagian yang utuh dari organisasi, dan konsekuensi lebih lanjut, guru merasa wajib untuk melaksanakan bersama apa yang telah diputuskan karena adanya rasa keterikatan dengan apa yang telah diciptakan bersama. Dengan demikian dapat diharapkan untuk lebih meningkatkan kinerja guru.

Masalah kinerja bagi guru adalah masalah yang sangat penting. Tanpa adanya kinerja yang baik tidak mungkin madrasah dapat menghasilkan peserta didik yang kompetitif. Peningkatan kinerja mempunyai implikasi yang positif bagi madrasah itu sendiri, artinya madrasah dapat menghasilkan kuantitas dan kualitas peserta didik yang optimal. Kinerja guru akan meningkat bila didukung oleh penerapan sistem manajemen kinerja dan sistem pengembangan karir yang baik dan efektif. Bila system menajemen kerja sudah meningkat secara otomatis mutu pendidikan di madrasah tersebut juga akan meningkat.

Untuk memiliki kinerja yang baik guru hendaknya memiliki beberapa kompetensi yang akan digunakan dalam melaksanakan tugasnya sebagai seorang pendidik. Berdasarkan Peraturan Menteri Pendidikan Nasional Republik Indonesia Nomor 16 Tahun 2007 tentang Standar Kualifikasi Akademik dan Kompetensi Guru dijelaskan bahwa standar kompetensi guru dikembangkan secara utuh dari 4 kompetensi utama, yaitu: (1) kompetensi pedagogik, (2) kepribadian, (3) sosial, dan (4) profesional. Keempat kompetensi tersebut terintegrasi dalam kinerja guru.

Sertifikasi adalah proses pemberian sertifikat pendidik kepada guru. Sertifikat pendidik ini diberikan kepada guru yang memenuhi standar profesional guru. Standar profesional guru tercermin dari uji kompetensi. Uji kompetensi dilaksanakan dalam bentuk penilaian portofolio. Penilaian portofolio merupakan pengakuan atas pengalaman profesional guru dalam 
bentuk penilaian terhadap kumpulan dokumen yang mendeskripsikan kualifikasi akademik, pendidikan dan pelatihan, pengalaman mengajar, perencanaan dan pelaksanaan pembelajaran, penilaian dari atasan dan pengawas, prestasi akademik, karya pengembangan profesi, keikutsertaan dalam forum ilmiah, pengalaman organisasi di bidang kependidikan.

Namun hal ini tidaklah mudah dilakukan, sebab banyak faktor yang mempengaruhi tinggi rendahnya kinerja yaitu bahwa unsurunsur yang mempengaruhi pencapaian kinerja adalah kemampuan (ability) dan motivasi (motivation). Motivasi seseorang ditentukan oleh intensitas motifnya (uang). Motivasi adalah penting karena sangat menentukan kinerja dan karena sifatnya tidak terwujud. Maka dari itu kinerja mengajar guru merupakan salah satu faktor dominan yang berpengaruh terhadap kompensasi dan motivasi.

Kompensasi merupakan apa yang diterima pekerja sebagai tukaran atas kontribusinya kepada organisasi, dan di dalam kompensasi terdapat sistem intensif yang menghubungkan kompensasi dengan kinerja. Kompensasi merupakan faktor penting untuk mempertahankan karyawan/pegawai, sebab suka tidak suka dan disadari atau tidak uang merupakan faktor penting dalam kehidupan yang dapat meningkatkan motivasi walaupun sulit untuk bisa memuaskan manusia. Selain kompensasi yang dibutuhkan dalam kinerja mengajar guru adanya motivasi sangat diperlukan, di mana motivasi yang rendah akan menghasilkan guru yang kinerja mengajarnya rendah, sedangkan motivasi yang tinggi akan membuat guru berusaha bekerja menjadi lebih baik dan menghasilkan kinerja mengajar guru yang berkualitas.

Berdasarkan hasil wawancara yang penulis lakukan pada tanggal 09 Februari 2015 dengan Kepala Madrasah Aliyah Swasta (MAS) Plus Padang Ganting, diperoleh informasi bahwa kinerja guru terlihat lebih baik setelah adanya sertifikasi terutama pada kelengkapan perangkat pembelajaran. Adapun fenomena yang terjadi di lapangan dari hasil pengamatan peneliti menunjukkan bahwa kinerja mengajar para guru itu relatif, ada guru yang sudah sertifikasi kinerjanya meningkat dan ada pula yang kinerjanya sama saja tidak ada perubahan yang signifikan, selain itu ada pula guru yang belum sertifikasi tetapi kinerjanya memang sudah bagus karena adanya berbagai pengalaman atau sebaliknya. Ada pula sebagian guru yang sudah tersertifikasi malah mempunyai motivasi yang kurang, jarang 
membuat program pengajaran dan evaluasi, serta keengganan menyelesaikan pekerjaan dalam membuat silabus dan menganalisis pembelajaran yang cocok untuk diajarkan pada siswa, karena berfikir yang penting sudah sertifikasi jadi mengajar hanya sebagai rutinitas bukan tanggung jawab, sehingga mempunyai kualifikasi kinerja mengajar yang sama dengan guru yang belum tersertifikasi padahal seharusnya yang terjadi guru yang sudah tersertifikasi harus lebih mampu mengembangkan kompetensinya dan memenuhi jam pelajaran sebanyak 24 jam serta lebih mampu berinovasi meskipun fasilitas pembelajaran/alat bantu dalam kegiatan mengajar belum memadai.

Indikator yang dijadikan ukuran meningkatnya kinerja guru MAS Plus Padang Ganting adalah, absensi kehadiran, jam masuk dan keluar kelas, batas pelajaran (ketentuan mengajar), kehadiran MGMP, kehadiran upacara bendera, kehadiran upacara hari Nasional dan kegiatan harihari besar lainnya serta kegiatan ekstra yang dilaksanakan oleh Madrasah. Indikator yang dijadikan ukuran kinerja guru MAS Plus Padang Ganting adalah kelengkapan perangkat pembelajaran guru tersebut, perencanaan pembelajaran, pelaksanaan pembelajaran, penilaian dan evaluasi pembelajaran, menganalisis tujuan pembelajaran, melakukan remedi serta penganyaan bagi setiap siswa untuk mencapai tujuan pembelajaran.

\section{KINERJA GURU}

Dalam Kamus Besar Bahasa Indonesia, kinerja merupakan hasil yang telah dicapai (dari yang telah dilakukan, telah dikerjakan). Kinerja diartikan sebagai: (1) sesuatu yang dicapai, (2) prestasi yang diperlihatkan, dan (3) kemampuan yang diperlihatkan dalam bekerja.

Kinerja dalam dunia organisasi diartikan sabagai tingkat keberhasilan seorang kayawan dalam melaksanakan atau menyelesaikan pekerjaannya. Kinerja ini mengandung makna beberapa dimensi yaitu dimensi kualitas (quality of work), dimensi kuantitas (quantity of work), dimensi kerja sama (coorporation with other's work). Menurut Heidjrachman dalam Rismen (1992) mengemukakan bahwa kinerja sama dengan prestasi kerja yaitu kemampuan seseorang dalam melaksanakan tugas dan tanggung jawabnya dalam melakukan pekerjaan.

Menurut Musanef (1985) kinerja adalah kemampuan seseorang dalam usaha mencapai hasil kerja yang baik atau lebih menonjol ke arah tercapainya tujuan organisasi. Anoraga berpendapat bahwa prestasi kerja merupakan hasil tingkah laku seseorang dalam pelaksanaan suatu kegiatan. 
As'at mengemukakan bahwa prestasi kerja adalah apa yang telah diciptakan dari hasil pekerjaan yang telah dilakukan atau diusahakan, hasil yang menyenangkan hati yang diperoleh dengan keuletan dan bekerja.

Indikator kinerja guru dalam penelitian ini dapat dilihat dari kemampuan guru dalam menyusun program belajar, melaksanakan proses pembelajaran, pelaksanaan evaluasi pembelajaran, pelaksanaan perbaikan dan pengayaan. Pada tahap perencanaan program pembelajaran adalah tahap yang berhubungan dengan kemampuan guru menguasai bahan ajar yang dapat dilihat dari cara atau proses penyusunan program kegiatan pembelajaran yang dilakukan oleh guru, di mana guru dituntut menyusun program tahunan dan program semester, serta program untuk setiap pokok bahasan. Unsur/komponen yang dimiliki oleh setiap satu pokok bahasan terdiri dari tujuan/ kompetensi pembelajaran, materi yang akan disajikan, kegiatan pembelajaran terdiri dari alternatif metode, penggunaan media dan sumber belajar, dan alat evaluasi yang digunakan.

Pada tahap evaluasi hasil belajar, guru dituntut memiliki kemampuan menentukan pendekatan atau cara-cara evaluasi, penyusunan alat evaluasi, pengolahan dan penggunaan hasil evaluasi untuk selanjutnya dapat dijadikan acuan pelaksanaan perbaikan dan pengayaan. Guru yang berkinerja baik adalah guru yang berilmu dan berkinerja berdasarkan ilmunya dengan lisan, tulisan, maupun keteladanannya, Allah menegaskan mereka memiliki derajat yang lebih baik. Standar kinerja perlu dirumuskan untuk dijadikan acuan dalam mengadakan perbandingan terhadap apa yang dicapai dengan apa yan diharapkan.

Kinerja guru dalam penelitian ini dipengaruhi oleh beberapa faktor antara lain intelegensi, sikap, kemampuan profesional, ketrampilan menajemen, keamanan, suasana atau kerja tim, perencanaan, kepemimpinan dan pengawasan. Faktor-faktor tersebut sebagaimana dikemukakan oleh Siagian (2002) bahwa ada beberapa faktor yang dapat mempengaruhi kinerja antara lain: (1) intelegensi, (2) sikap, (3) kemampuan professional guru, (4) keterampilan menajemen, (5) suasana atau iklim kerja, (6) keamanan dan perlindungan kerja, (7) perencanaan, (8) pengawasan, (9) motivasi internal, (10) kepemimpinan kepala sekolah.

Cara mengukur kinerja guru dapat dilakukan antara lain dengan penilaian kinerja guru yaitu sebagai proses formal yang dilakukan untuk mengevaluasi pelaksanaan pekerjaan atau unjuk kerja seorang guru dan memberikan umpan balik untuk kesesuaian tingkat kerja dalam periode tertentu. 
Menurut Permenpan dan RB No.16/2009 Peraturan baru yang terdiri dari 13 Bab dan 47 pasal, secara keseluruhan mengandung semangat yang bertujuan untuk meningkatkan kompetensi dan profesionalisme guru yang selanjutnya akan menjadikan guru sebagai pekerjaan profesional yang dibingkai oleh kaidahkaidah profesi yang standar. Peraturan ini terbit dalam rangka memberi ruang dan mendukung pelaksanaan tugas dan peran guru agar menjadi guru yang profesional. Perubahan peraturan ini diharapkan berimplikasi terhadap peningkatan mutu, kreatifitas dan tentu saja kinerja guru.

Penilaian Kinerja Guru yang sebelumnya lebih bersifat administratif menjadi lebih berorientasi praktis, kuantitatif, dan kualitatif, sehingga diharapkan para guru akan lebih bersemangat untuk meningkatkan kinerja dan profesionalitasnya. Guru dinilai kinerjanya secara teratur (setiap tahun) melalui Penilaian Kinerja Guru (PK Guru), Guru wajib mengikuti Pengembangan Keprofesian Berkelanjutan (PKB) setiap tahun.

\section{SERTIFIKASI GURU}

Sertifikasi adalah profesi menurut proses pengakuan kompetensi. Menurut Muslieh (2007) sertifikasi adalah proses pemberian sertifikasi pendidikan kepada guru yang telah memenuhi persyaratan tertentu, yaitu memiliki kualifikasi akademik, kompetensi sehat jasmani dan rohani, serta memiliki kemampuan untuk mewujudkan tujuan Pendidikan Nasional yang dibarengi dengan peningkatan kesejahteraan yang layak.

Herawati (2009) mengemukakan sertifikasi adalah proses pemberian sertifikat kepada guru-guru yang telah memenuhi standar kompetensi guru. Program sertifikasi adalah implikasi dari UU Sikdiknas tahun 2003, UU Guru dan Dosen No. 14 Tahun 2005, UU tentang Standar Nasional Pendidikan tahun 2006, serta dikuatkan dengan adanya Permendiknas No. 18 tahun 2007 tentang sertifikasi guru dalam jabatan. Dengan adanya sertifikasi pendidik guru tersebut berhak mendapat tunjangan profesi.

Dalam Undang-Undang Guru dan Dosen (UUGD) pasal 16 disebutkan bahwa guru yang memiliki sertifikat pendidik, berhak mendapatkan insentif yang berupa tunjangan profesi. Peningkatan kesejahterann guru dalam kaitannya dengan sertifikasi harus dipahami dalam kerangka peningkatan mutu pendidikan nasional, baik dari segi proses (layanan) maupun hasil (luaran) pendidikan. Peraturan Pemerintah No. 19 Tahun 2005 tentang Standar Nasional Pendidikan secara eksplisit mengisyaratkan adanya standarisasi isi, proses, kompetensi lulusan, pendidik dan tenaga kependidikan, sarana dan 
prasarana, pengelolaan, pembiyaan, dan penilaian pendidikan dalam mencapai tujuan pendidikan nasional. Dengan adanya sertifikasi, diharapkan kompetensi guru sebagai agen pembelajaran akan meningkat sesuai dengan standar yang telah ditetapkan. Dengan kompetensi guru yang memenuhi standar minimal dan kesejahteraan yang memadai diharapkan kinerja guru dalam mengelola proses pembelajaran dapat meningkat. Kualitas pembelajaran yang meningkat diharapkan akan bermuara akhir pada terjadinya peningkatan prestasi hasil belajar siswa.

Peraturan Pemerintah No. 19 Tahun 2005 tentang Standar Nasional Pendidikan secara eksplisit mengisyaratkan adanya standarisasi isi, proses, kompetensi lulusan, pendidik dan tenaga kependidikan, sarana dan prasarana, pengelolaan, pembiyaan, dan penilaian pendidikan dalam mencapai tujuan pendidikan nasional. Perlu disadari bahwa guru adalah subsistem pendidikan nasional. Dengan adanya sertifikasi, diharapkan kompetensi guru sebagai agen pembelajaran akan meningkat sesuai dengan standar yang telah ditetapkan. Dengan kompetensi guru yang memenuhi standar minimal dan dengan kesejahteraan yang memadai diharapkan kinerja guru dalam mengelola proses pembelajaran dapat meningkat. Kualitas pembelajaran yang meningkat diharapkan akan bermuara akhir pada terjadinya peningkatan prestasi hasil belajar siswa.

\section{METODE PENELITIAN}

Jenis penelitian ini adalah kualitatif dengan metode studi kasus (case study) (Sugiyono, 2010) untuk membuktikan keadaan sebenarnya dari fenomena objek yang diteliti dan dibandingkan dengan teori yang sesuai dengan masalah ini. Penelitian ini mengungkap tentang peningkatan kinerja guru di MAS Plus Padang Ganting setelah pelaksanaan sertifikasi.

Pengumpulan data dalam penelitian ini dilakukan dengan cara penelitian lapangan, yaitu terjun langsung di lokasi penelitian untuk mendapatkan data yang diperlukan. Teknik pengumpulan data yang peneliti gunakan dalam penelitian ini adalah observasi, wawancara dan studi dokumentasi.

Data dan sumber data penelitian ini adalah semua guru di MAS Plus Padang Ganting yang berjumlah 40 orang. Guru Pegawai Negeri Sipil (PNS) yang sudah sertifikasi yang menambah jam mengajar di MAS Plus Padang Ganting sebanyak 15 orang. Guru non Pegawai Negeri Sipil (PNS) atau guru honorer yang sudah sertifikasi di MAS Plus Padang Ganting sebanyak 5 orang. 
Analisis data dalam penelitian ini dilakukan pada saat pengumpulan data berlangsung dan setelah selesai pengumpulan data dalam periode tertentu. Pada saat wawancara peneliti sudah melakukan analisis terhadap jawaban yag diwawancarai. Bila jawaban yang diwawancarai setelah dianalisis merasa belum memuaskan, maka peneliti melanjutkan pertanyaan lagi, sampai tahap tertentu diperoleh data yang dianggap valid. Miles dan Huberman (1994) mengemukakan bahwa aktifitas dalam analisis data kualitatif dilakukan secara interaktif dan berlangsung secara terus menerus sampai tuntas, sehingga datanya jenuh. Aktivitas dalam analisis data penelitian kualitatif antara lain data reduction, data display dan conclusion drawing/ verification. Selanjutnya model interaktif dalam analisis data ditunjukkan pada gambar berikut:

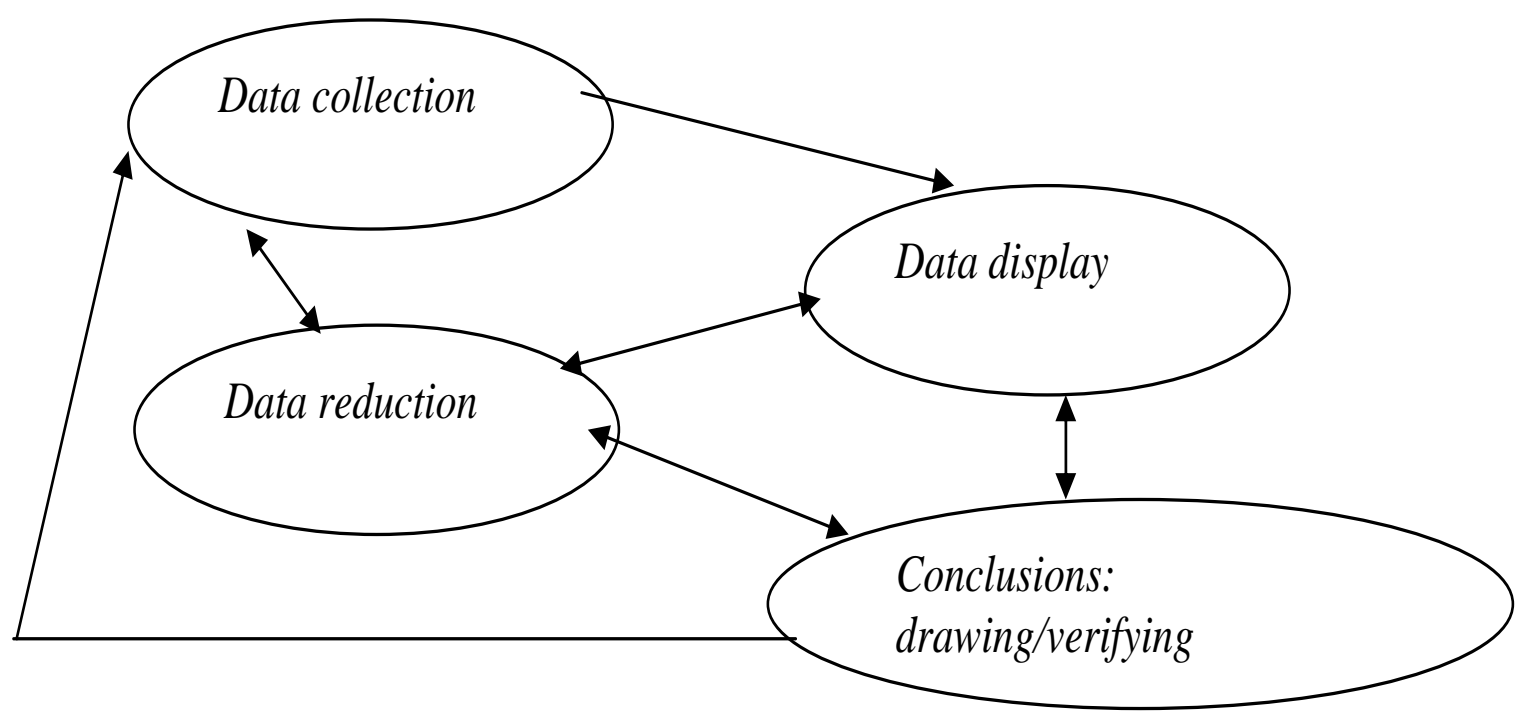

Gambar: Komponen dalam Analisis Data (interactive model)

Menurut Sutopo (2002) uji keabsahan data dalam penelitian kualitatif meliputi uji credibility (validitas internal), transferability (validitas eksternal), dependability (reliabilitas), dan confirmability (objektivitas).

\section{HASIL PENELITIAN DAN PEMBAHASAN}

1. Kinerja Guru PNS yang telah Sertifikasi Pada Madrasah Aliyah Swasta (MAS)

\section{Plus Padang Ganting Kabupaten Tanah Datar}

Setelah mengikuti diklat sertifikasi merasakan ada perkembangan dan kemajuan yang pesat dalam diri para guru PNS yang telah disertifikasi sehingga mereka bisa lebih profesional dalam melakukan KBM (kegiatan belajar mengajar) dibanding dengan sebelumnya. Guru PNS yang telah disertifikasi 
mengatakan, ketika saya kuliah, materi yang saya pelajari adalah tentang macam-macam metode pengajaran akan tetapi metodemetode tersebut tidak pernah dipraktikkan dan hanya menggunakan metode ceramah dan demonstrasi saja jika mengajar.

Akan tetapi menurut beliau di dalam diklat sertifikasi metode-metode tersebut diajarkan lagi dan disuruh mempraktikkan didepan teman-teman diklatnya. Setelah menjalani diklat sertifikasi saya sering menggunakan metode-metode yang bervariasi yang telah didapat dari diklat sertifikasi, metode-metode tersebut adalah sebagai berikut, metode akulturasi, metode kritikal insiden, metode jigsaw, metode diskusi dan demonstrasi.

Di dalam metode akulturasi siswa yang dilakukan oleh guru PNS yang telah disertifikasi dibentuk beberapa kelompok kemudian masing-masing kelompok disuruh untuk praktik secara bergantian dan hasil praktik tersebut akan dinilai oleh temantemannya sendiri, apabila dalam praktik tersebut masih terdapat kesalahan atau kekurangan maka akan dilaporkan kepada guru yang bersangkutan agar mendapatkan pembimbingan lagi. Sedangkan di dalam metode kritikal insiden siswa disuruh untuk bercerita mengenai pengalaman hidupnya yang berhubungan dengan mata pelajaran tersebut kemudian dari cerita tersebut guru mengambil kesimpulan bagaimana mengkorelasikan antara pengalaman dengan materi pelajaran, metode ini juga sering disebut sebagai metode yang mengkritisi pengalaman penting.

Cara mengajar guru PNS yang telah disertifikasi mengalami perkembangan, di antaranya metode pembelajaran yang digunakan lebih bervariasi, metode yang biasa digunakan diantaranya, ceramah, metode jigsaw, diskusi, tanya jawab dan artukulasi, sehingga membuat siswa senang dalam mengikuti kegiatan belajar mengajar dan mengakibatkan nilai-nilai siswa menjadi bagus. Setelah menempuh diklat sertifikasi guru PNS yang telah disertifikasi juga mendapatkan hal baru, di antaranya dalam menghadapi murid, sebelum diklat sertifikasi dalam menghadapi murid agak kurang percaya diri akan tetapi setelah menjalani diklat sertifikasi hal-hal tersebut mulai hilang dan selalu percaya diri dan yakin dengan kemampuannya.

Faktor pendukung dan penghambat dalam meningkatkan kinerja guru PNS yang telah disertifikasi. Faktor pendukung yang paling utama di MAS Plus Padang Ganting adalah lingkungan karena lingkungannya dekat dengan mushalla sehingga memudahkan guru PNS yang telah 
disertifikasi untuk melaksanakan kegiatan praktek secara langsung di mushalla tersebut, sedangkan faktor pendukung selanjutnya adalah sarana dan prasarana yang sangat memadai mulai dari mushalla, ruang kelas yang nyaman, perpustakaan yang lengkap dan guru-guru yang berkompeten dalam bidangnya.

Selain itu kalau datang tepat waktu dan pulang pun dengan tepat waktu, sehingga absen kehadiran setiap bulannya selalu $100 \%$ hadir. Usaha Informan VII dalam meningkatkan pembelajaran biasanya beliau sering mengadakan praktek-praktek secara langsung untuk mata pelajaran yang beliau ajarkan. guru PNS yang telah sertifikasi alhamdulillah dengan pelaksanaan sertifikasi, disiplin sudah ada perubahan dan kinerjanya juga sudah ada perubahan pak, walaupun sebahagian kecil belum nampak perubahan.

Motivasi mengajar adalah salah satu dorongan diri untuk melakukan sesuatu dengan cara menyalurkan ilmu yang didapatkan. Kemudian mengamalkan ilmu hukumnya wajib dan bila mengerjakannya hanya karena mendapat balasan di dunia maka akan sia-sia, tapi bila diniatkan sebagai pengabdian dunia dan akhirat maka akan timbul keikhlasan untuk mendapatkan berkah dari Allah SWT. Itu lah yang coba saya tanamkan dalam diri saya

\section{Kinerja Guru Non PNS Yang Telah Sertifikasi Pada Madrasah Aliyah Swasta (MAS) Plus Padang Ganting Kabupaten Tanah Datar}

Untuk mengetahui kinerja guru non PNS yang telah sertifikasi, peneliti mencari informasi dari berbagai sumber melalui wawancara, observasi dan dokumen. Kinerja guru non PNS yang telah sertifikasi mengenai kinerjanya sudah ada perubahan walaupun sebahagian kecil belum Nampak hasilnya. Sedangkan kepala MAS Plus Padang Ganting juga menyampaikan hal yang sama mengenai kinerja sudah ada peningkatan kinerja pasca pelaksanaan sertifikasi.

Sedangkan kinerja guru non PNS yang telah sertifikasi, kinerjanya guru non PNS yang telah sertifikasi beberapa orang guru sudah ada peningkatan dan sebahagian lagi belum ada peningkatan. Kepala TU MAS Plus Padang Ganting, juga mengungkapkan, mengenai kinerjanya juga ada peningkatan setelah sertifikasi namun belum signifikan.

Peneliti juga mendapatkan informasi dari guru bidang studi lain, tentang kinerja guru non PNS yang telah sertifikasi Guru B. Inggris MAS Plus Padang Ganting dan kawan-kawan mereka menyampaikan kinejanya juga baik, sesuai dengan tugas pokok. 
Untuk mengetahui kelengkapan perangkat pembelajaran guru non PNS yang telah sertifikasi MAS Plus Padang Ganting, peneliti memperoleh informasi dari wakilwakil kepala bidang kurikulum masingmasing madrasah. Pertama kali peneliti mendapat informasi data wakil kepala bidang kurikulum MAS Plus Padang Ganting, sewaktu peneliti meminta informasi, beliau mengatakan perangkat pembelajaran guru non PNS yang telah sertifikasi sebahagian besar lengkap.

Seiring disiplin guru non PNS yang telah sertifikasi MAS Plus Padang Ganting cukup bagus, mengajar tepat waktu. Sedangkan Kepala MAS Plus Padang Ganting juga mengatakan ada peningkatan disiplin dan kinerja guru non PNS yang telah sertifikasi.

Untuk mengetahui tingkat kehadiran dan absensi guru non PNS yang telah sertifikasi MAS Plus Padang Ganting, peneliti memperoleh informasi dari nara sumber melalui wawancara. Menurut Wakil Kepala Bidang kurikulum MAS Plus Padang Ganting, dalam wawancaranya dengan peneliti mengungkapkan alhamdulillah ada peningkatan pak, mengenai kehadiran di madrasah bagus, karena kehadiran tidak hanya pada sertifikasi tetapi juga berpengaruh terhadap materi yang akan diajarkan kepada para siswa.
Untuk mendapatkan motivasi kerja yang tinggi bagi kelangsungan produktivitas kinerja guru non PNS Yang Telah Sertifikasi di MAS Plus Padang Ganting tersebut dibutuhkan suatu landasan yaitu terdapatnya suatu motivator. Dan hal ini merupakan suatu pemikiran dan kebijaksanaan yang tertuang dalam perencanaan dan program yang terpadu dan disesuaikan dengan situasi dan kondisi sesuai dengan keadaan ekstern dan intern MAS Plus Padang Ganting.

Kepala MAS Plus Padang Ganting, sebagai motivator dalam wawancara dengan penulis mengatakan, bahwa sebagai top leadership di MAS Plus Padang Ganting beliau tak henti-hentinya memberi motivasi kerja bagi guru-guru Yang Telah Sertifikasi di MAS Plus Padang Ganting.

Guru non PNS yang telah sertifikasi mempunyai motivasi kerja, maka mereka akan terdorong dan berusaha untuk meningkatkan kemampuannya dalam pembelajaran, ekstra kurikuler, lembaga, masyarakat dan profesionalnya sebagai guru dalam meningkatkan kinerjanya di sekoah sehingga diperoleh hasil kerja yang maksimal, begitu juga yang ikhtiar yang dilakukan oleh pimpinan MAS Plus Padang Ganting yang tak henti-hentinya meberi guru MAS Plus Padang Ganting mempunyai motivasi kerja yang tinggi, karena dengan motivasi kerja yang tinggi tersebut mereka akan terdorong dan 
berusaha untuk meningkatkan kemampuannya dalam pembelajaran, ekstra kurikuler, lembaga, masyarakat dan profesionalnya sebagai guru dalam meningkatkan kinerjanya di MAS Plus Padang Ganting sehingga diperoleh hasil kerja yang maksimal sesuai dengan visi misi MAS Plus Padang Ganting yang telah disepakati bersama.

\section{KESIMPULAN}

Guru PNS yang Telah Sertifikasi Pada Madrasah Aliyah Swasta (MAS) Plus Padang Ganting Kabupaten Tanah Datar, baik PNS maupun non PNS memiliki kinerja yang baik. Hal ini terbukti, pertama dilihat dari segi absensi/kehadiran guru PNS rata-rata 95\%. Sementara guru non PNS yang yelah sertifikasi terdapat peningkatan absensi dalam menjalankan tugas bila disbanding dengan guru honorer yang tidak sertifikasi. Hal ini dapat dilihat melalui data dan daftar hadir, ini membuktikan bahwa motivasi kerja guru sertifikasi baik PNS maupun non PNS cukup tinggi. Di samping itu dilihat dari segi kedisiplinan secara umum guru PNS yang telah sertifikasi mempunyai disiplin yang baik begitu juga guru non PNS. Motivasi yang tinggi baik yang datangya dari dalam maupun dari luar. Guru PNS yang telah setifikasi dalam proses pembelajaran telah mengalami perkembangan di antaranya menggunakan metode yang bervariasi, metode yang biasa digunakan di antaranya, ceramah, metode jigsaw, diskusi, tanya jawab dan artukulasi, sehingga membuat siswa senang dalam mengikuti proses pembelajaran dan pada akhirnya para siswa memperoleh nilai yang bagus.

Guru non PNS yang telah sertifikasi pada Madrasah Aliyah Swasta (MAS) Plus Padang Ganting Kabupaten Tanah Datar memiliki kinerja yang kurang baik dalam Proses Pembelajaran, tidak semua guru non PNS membuat Rencana Persiapan Pembelajaran (RPP), karena masih ada yang belum membuat program remedial dan program pengayaan. Dilihat dari segi keaktifan dalam berbagai kegiatan di madrasah baik kegiatan kurikuler maupun estrakurikuler guru PNS yang defenitif dan guru honorer terlihat lebih aktif, karena mereka mempunyai waktu lebih banyak ketimbang guru PNS yang menambah jam di madrasah ini, seperti mengikuti upaca bendera, muhadharah, mengikuti kegiatan hari besar Islam dan kegiatan lainnya.

\section{KEPUSTAKAAN ACUAN}

Herawati, Susi. (2009). Etika \& Profesi Keguruan. Batusangkar: STAIN Batusangkar Press.

Miles, Mathew B \& Huberman, A. Michael. (1994). Qualitative Data Analysis. An
74

Jurnal al-Fikrah, Vol. III, №. 1, Januari-Juni 2015 
Expanded Sourcebook Second Edition. Thousand Oaks, CA: Sage.

Musanef. (1985). Manajemen Kepegawaian Indonesia. Jakarta: Gunung Agung.

Muslieh, Mansur. (2007). Sertifkasi Guru Menuju Profesionalisme Pendidik. Jakarta: Bumi Aksara.

Peraturan Menteri Pendidikan Nasional Republik Indonesia Nomor 16 Tahun 2007 tentang Standar Kualifikasi Akademik dan Kompetensi Guru

Peraturan Menteri Pendidikan Nasional No. 18 tahun 2007 tentang Sertifikasi Guru dalam Jabatan

Peraturan Menteri PAN dan RB No.16/2009

Peraturan Pemerintah No. 19 Tahun 2005 tentang Standar Nasional Pendidikan

Rismen, Sefna. (1992). Kontribusi Motivasi Berprestasi dan Persepsi Guru tentang
Pengawasan Kepala Sekolah terhadap Kinerja Guru Madrasan Aliyah Negri (MAN) Kodya Padang. Tesis Program Pascasarjana Universitas Negeri Padang. Siagian, Sondang P. (2002). Menajemen Sumber Daya Manusia. Jakarta: Bumi Aksara.

Sugiyono, Metode Penelitian Kuantatif, Kualitatif dan $R$ \& $D$, Bandung: CV. Alfabeta, 2010.

Sutopo, HB. (2002). Metodologi Penelitian Kualitatif. Surakarta: UNS Press

Undang-Undang Sistem Pendidikan Nasional Tahun 2003

Undang-Undang Guru dan Dosen No. 14 Tahun 2005

Undang-Undang tentang Standar Nasional Pendidikan tahun 2006 